\title{
A comprehensive genomic meta-analysis identifies confirmatory role of OBSCN gene in breast tumorigenesis
}

\author{
Barani Kumar Rajendran ${ }^{1}$ and Chu-Xia Deng ${ }^{1}$ \\ ${ }^{1}$ Cancer Research Centre, Faculty of Health Sciences, University of Macau, Macau SAR, China \\ Correspondence to: Chu-Xia Deng, email: cxdeng@umac.mo \\ Keywords: breast cancer, OBSCN gene, OBSCURIN, cell adhesion, EMT
}

Received: May 25, 2017 Accepted: July 26, $2017 \quad$ Published: August 23, 2017

Copyright: Rajendran et al. This is an open-access article distributed under the terms of the Creative Commons Attribution License 3.0 (CC BY 3.0), which permits unrestricted use, distribution, and reproduction in any medium, provided the original author and source are credited.

\section{ABSTRACT}

The giant multifunctional protein "OBSCURIN" is encoded by OBSCN gene and is mostly expressed in cardiac and other skeletal muscles responsible for myofibrils organization. Loss of OBSCURIN affects the entire downstream pathway proteins vital for various cellular functions including cell integration and cell adhesion. The OBSCN gene mutations are more frequently observed in various muscular diseases, and cancers. Nevertheless, the direct role of $O B S C N$ in tumorigenesis remains elusive. Interestingly, in clinical breast cancer samples a significant number of function changing mutations have been identified in $O B S C N$ gene. In this study, we identified a significant role of $O B S C N$ by conducting an integrative analysis of copy number alterations, functional mutations, gene methylation and expression data from various BRCA cancer projects data available on cBioPortal and TCGA firebrowse portal. Finally, we carried out genetic network analysis, which revealed that $O B S C N$ gene plays a significant role in GPCR, RAS, p75 or Wnt signaling pathways. Similarly, OBSCN gene interacts with many cancer-associated genes involved in breast tumorigenesis. The $O B S C N$ gene probably regulates breast cancer progression and metastasis and the prognostic molecular signatures such as copy number alterations and gene expression of OBSCN may serve as a tool to identify breast tumorigenesis and metastasis.

\section{INTRODUCTION}

Cancer in humans is a huge health burden in modern era worldwide. In recent years cancer genomics is assumed as a latest advancement in cancer research, which starts from disease identification and leads to personalized therapy. Owing to this scientific advancement, several key genetic elements have been identified and characterized in various cancer types. In human carcinogenesis events, cells lose their adhesion, integrity and others morphological characteristics and gain the invasive and migratory properties leading to cellular transitions which are called epithelial-to-mesenchymal transition (EMT), which is the most crucial step in initiating cancer metastasis $[1,2]$. Large number of genes and their corresponding proteins are involved in EMT associated pathway including OBSCURIN. The giant OBSCURIN is encoded by unique gene called $O B S C N$ located on chromosome 1 at loci q42 [3]. The giant OBSCURIN has two isoforms namely
OBSCURIN-A \& B [4-6]. The OBSCURIN-A comprises of immunoglobulin (Ig) and fibronectin type-III domains located in the amino terminal while in carboxyl terminal contains several signaling domains including Isoleucin \& Glutamine calmodulin-binding (IQ), SRC homology-3 (SH3) domains, pleckstrin homology (PH) and a Rhoguanine nucleotide exchange factor (Rho-GEF) domains which are scattered in the non-modular sequences. The OBSCURIN-B or myosin light chain kinase (MLCK) isoform contains two serine/threonine kinase (STK) domains, which replace the non-modular carboxyl terminus of OBSCURIN-A. Additional to these domains, ERK kinase domain exists for phosphorylation along with two Ig domains $[3,4,7,8]$. Every OBSCURIN domain regulates vast number of cellular and functional roles such as cell adhesion, migration and cell morphology, etc. Apart from these functional roles, OBSCURIN-A/B are also involved in cellular co-ordination that prevents cells from going in an EMT process [4, 9]. OBSCURIN 
MLCK family domains chiefly maintain the cellular organizations and contractility [10]. Moreover, a huge number of copy number alterations and mutations were observed in $O B S C N$ gene in many cancer types, although, $O B S C N$ is highly mutated in breast cancer. The main study is to uncover the functional mutations and the active role of $O B S C N$ in breast tumorigenesis. A few studies on this gene also proved that, the reduced or altered $O B S C N$ gene expression largely disturbs the cellular integration and activates cancer initiation; therefore, $O B S C N$ may function as a tumor suppressor gene and prevent cellular transition $[11,12]$. $O B S C N$ gene is mostly expressed in many cancer types although the real functional association in cancer is still uncertain. Several studies on $O B S C N$ gene mutations revealed potential roles of OBSCURIN in melanoma, glioblastoma, colorectal, lung, breast and pancreatic cancer [13-15]. Also, our recent study on breast cancer driver mutations genes also emphasized $O B S C N$ as one among the 63 top candidate driver genes [16]. Here we will mainly focus on copy number variation, non-silent mutations, promotor methylation followed by epigenetic changes and their consequences in breast cancer formation.

\section{Mutations and expression of $O B S C N$ : genetic predisposition to tumorigenesis}

Recent advances in high throughput sequencing support genomics in a magnificent way. In every cancer, vast numbers of genes are mutated, therefore the identification of real genetic elements responsible for carcinogenesis becomes quiet challenging. OBSCN gene is frequently and consistently mutated in various cancers with a strong correlation with breast, colorectal and other female related cancers. Recent studies revealed that TP53 and OBSCN genes are highly mutated among 189 candidate genes in breast and colorectal cancers $[13,17]$. However, scientific background on $O B S C N$ mutation and its impacts are limited in comparison to the other key genes involved in breast cancer $[18,19]$. Mutations in $O B S C N$ gene $(>15 \%)$ are observed in breast cancer patient samples published by TCGA. Furthermore, a recent study on $O B S C N$ gene in breast cancer revealed that the loss of giant OBSCURIN protein increases the cell migration with more metastatic characteristics [20].

However, recent studies revealed that OBSCURIN expression loss causes functional abnormality, which increases the probability of cancer in human breast epithelial cells. Perry et al. (2012) found that knocking down $O B S C N$ significantly affected breast epithelial cells in both growth and biological property, such as cellular adhesions, cell-cell communications, etc. As a result, expression level of other interlinked proteins such as E-cadherin, $\alpha$ and $\beta$-catenin involved in cell-cell junctions were largely affected. Meanwhile, an elevated level of p120-catenin prevents the cell adhesion and stimulates mesenchymal proteins, which stimulate cellular morphogenesis leading to metastasis [21-23]. The actin and microtubule cytoskeleton dysregulation is responsible for cellular transformation and migration found in many cancers and activation and deactivation of Rho-GTPase family proteins majorly regulates actin filaments through Ras homolog gene family, member A (RHOA) signaling. The loss of $O B S C N$ caused RHOA signaling impairment leading to breast cancer initiation, progression and metastasis. [12, 24-28]. The consequent event of $O B S C N$ loss may also affect tubulin microtentacles (McTN) formation. McTN is the key process in metastatic breast cancer and it increases metastatic probability and endothelial coupling followed by circulating tumor cells (CTC) [29-31].

Similarly, low levels of epithelial proteins accelerate phenotypic changes in cells, which further affect focal adhesion and increase of F-actin dynamics in cell-cell contacts [28]. Another interesting study proved that, an active oncogene, $K-R A S$ in the $O B S C N$ knockdown cells increases tumorigenesis probability [9]. The $O B S C N$ down regulation also affected RHOA-mediated pathways leading to dramatic reduction of Rho activated kinase (ROCK) and its targeting proteins such as myosin light chain (MLC), lim kinase (LimK) and cofilin [4, 8, 22, 29, 30]. In this study, we reviewed and analyzed $O B S C N$ gene and its association with breast cancer. The high throughput sequencing data for breast cancer mutations in clinical samples were retrieved from various breast cancer projects available in cBioPortal (www.cbioportal.org), Pan-Cancer (https://www.synapse.org), mRNAseq and Methylation data were retrieved from Firebrowse (http://firebrowse. org/) data portal, which provides multi-tier cancer analysis. The analyses of the overall mutation rates and the mutational patterns of $O B S C N$ gene, as well as their impact on downstream pathways may help us to predict feasible drug targets for breast cancer.

\section{The $O B S C N$ mutations in human cancers using high throughput analysis}

Apart from breast cancer, $O B S C N$ gene is widely mutated in many other cancer types as well (Supplementary Figure 1) (www.cbioportal.org). Among the various cancer types breast cancer cases are observed with significant numbers of $O B S C N$ mutations $(n=819)$ with average mutation frequency of $18 \%$. The overview of this work and study selection are given in the Figure 1 . The overall mutations percentage of OBSCN gene in various breast cancer projects are illustrated in Figure 2 (www. cbioportal.org). The large numbers of functional mutations were observed and $O B S C N$ copy number analyses were performed using GISTIC program and many copy gain, amplification and few deletion mutations were observed in major breast cancer projects data (Figure 3). From the overall DNA copy number analysis, we found that $O B S C N$ 


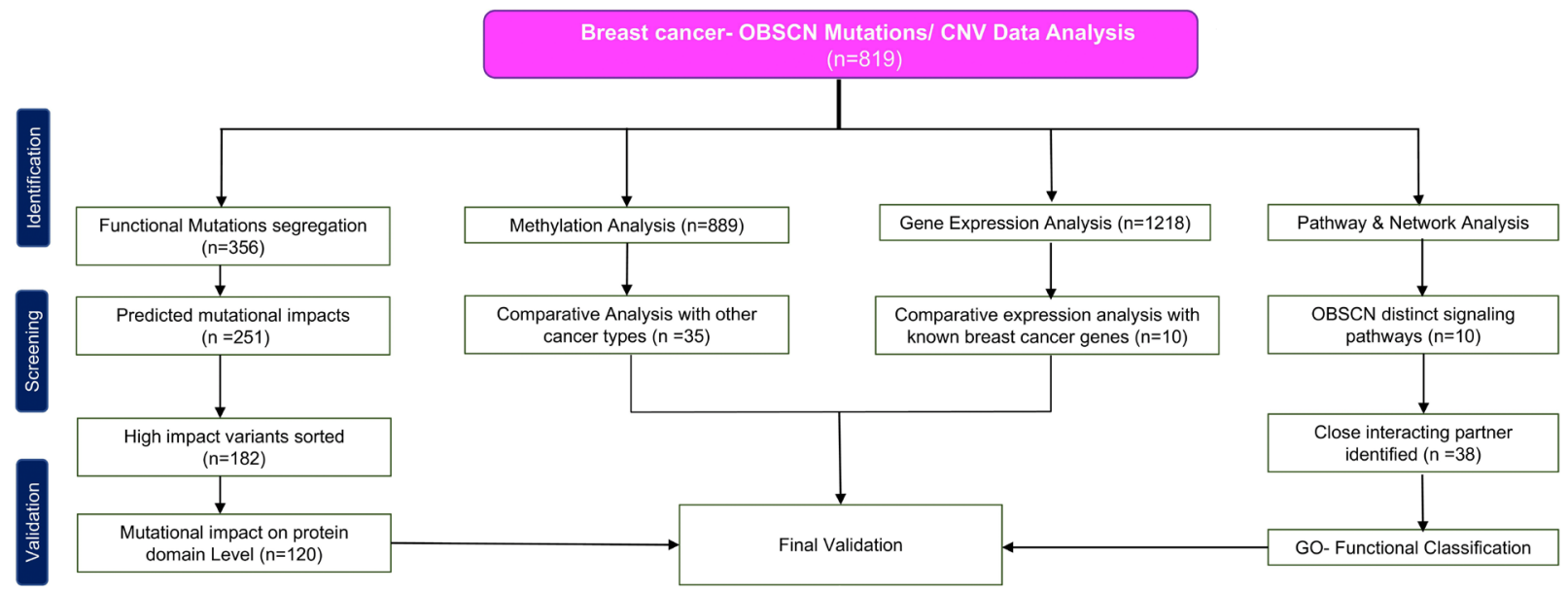

Figure 1: Flow diagram summarizing selection and validation of the present meta-analysis on OBSCN gene.

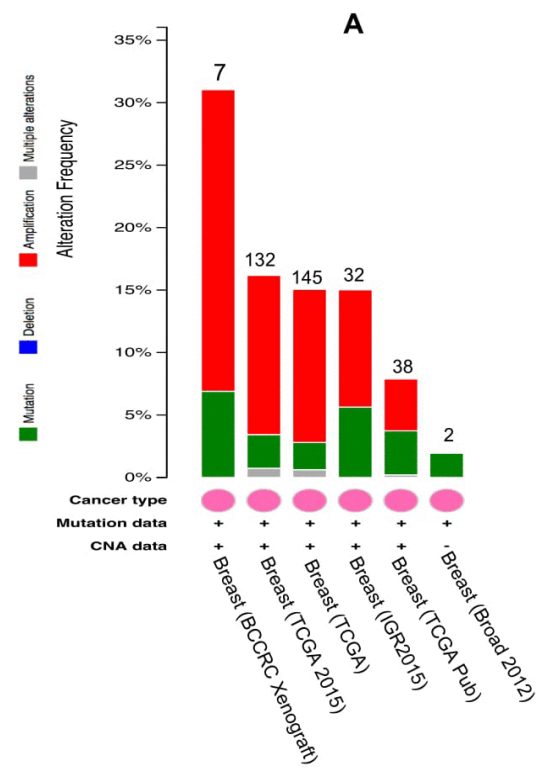

B

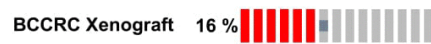

TCGA 2015 16\% |||||||||||||||||||||||||||||||||||||||||||||||||||||||||||||||||||||||||||||||||||||||||||||||||||||||||||||||||||||||||||||||||

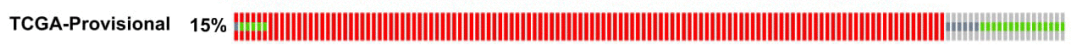

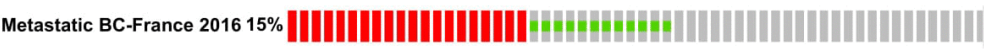

TCGA- Nature $2012 \quad 8 \%$ |||||||||||||||||||||||||||||||||||||||||||||||||||||||||||

BROAD- Nature 2012 1.9\% ||||||||||||||||||||||||||||||||||||||||||||||||||||||||||||||||||||||||||||||||||||||||||||||||||||||||

|Amplifcation "Truncaing Muation (putative passenger) "Mssense Nutaion (putative passenger|

Figure 2: Overall $O B S C N$ gene mutations across various breast cancer projects data of cBioportal. (A) number of $O B S C N$ mutations/copy number variations found in each project; (B) Distribution of $O B S C N$ gene mutations across the patient samples (\%).

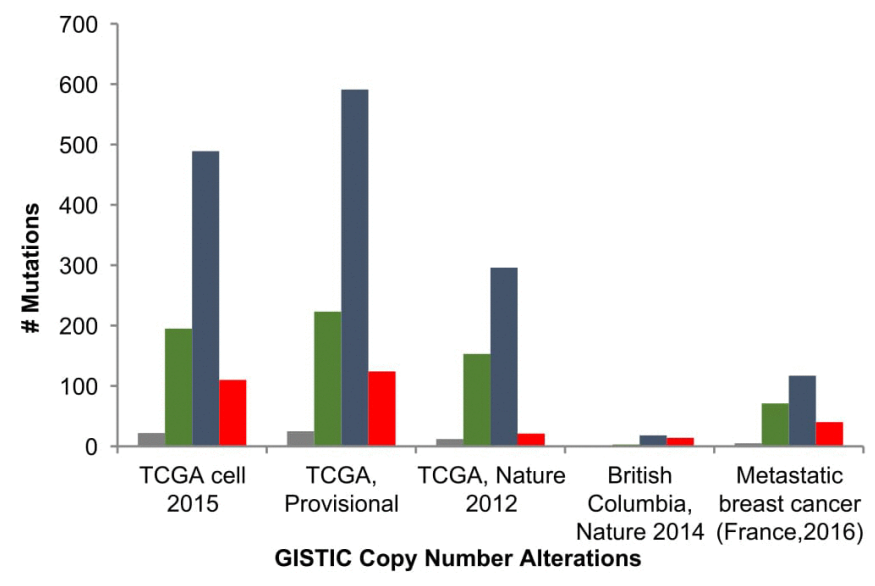

= shallow Del = Diploid = Gain $\quad$ High Level Amplification

Figure 3: GISTIC copy number analyses of $O B S C N$ gene in various breast cancer projects found with more number of gain and amplification mutations. 
gene had more number of copy gain and amplification mutations and these variations may potentially affect the giant OBSCURINs protein level and their subsequent expression.

The significant copy number alterations are observed and their outcomes are predicted using GISTIC copy number analysis [32]. The overall mutation profiles of $O B S C N$ gene in breast cancer shallow loss, diploid, gain and high level amplifications are classified based on distinctive copy number profiles and their clinical settings $[33,34]$. This analysis also revealed a huge number of gain and high level amplification mutations in $O B S C N$ gene found in invasive ductal carcinoma (IDC), followed by invasive lobular carcinoma (ILC) and so on. These results indicated that $O B S C N$ gene might play an active role in invasion of cancer cells to distant organs and other metastatic processes. The subsequent mRNA expression analysis was performed using breast cancer patient data and based on the median $\log 2$ value, the $O B S C N$ gene is seen down regulated in majority of the mutated TCGA data. To confirm the OBSCN gene expression we also compared with other well-known breast cancer genes such as TP53, PIK3CA, ARIDIA, BRCA1, etc. and found that these genes had closer expression levels and it indicated that $O B S C N$ gene mutations may also have a positive correlation with breast cancer dispositions (Figure 4) (https://cran.r-project.org/); (www.cbioportal. org); (https://cancergenome.nih.gov/). In addition to that, $O B S C N$ methylation profiles were also assessed using breast cancer methylation data by calculating beta value and found $O B S C N$ gene apparently hypermethylated. Then we compared methylation profiles of $O B S C N$ gene over various cancer types and found the gene is hyper-methylated in breast cancer data, which indicates its methylation may also play an important role in disease etiology. We used promotor methylated and gene expression samples of $O B S C N$ gene from TCGA wanderer (http://maplab.imppc.org/wanderer/). The $O B S C N$ methylation and gene expression was compared with normal $(n=98)$ and tumor $(n=720)$ samples at $\operatorname{cg} 09411356$ and interestingly, the hyper methylation on $O B S C N$ gene significantly reduced gene expression in tumor than the normal samples. The detailed methylation profile of single probe and its corresponding gene expression and comprehensive comparison of methylation pattern over major cancer types is depicted in Figure 5. (https://xenabrowser.net/\#). The downregulation of $O B S C N$ may affect cell-cell adhesion of breast epithelial cells and cells undergo EMT process [12]. Further we analyzed the expression of $O B S C N$ gene in various immunohistochemical breast cancer molecular subtypes. Nearly $73 \%$ cases found with luminal A $(46.99 \%)$ and luminal B (26.05\%) type of disease followed by other subtypes including basal (10.7\%), Her2(8.9\%), normal $(3.78 \%)$ and claudin-low (3.56\%). These molecular subtypes classifications distinctly emphasized, $O B S C N$ is vital gene may involve in the cell proliferation. Moreover, several previous studies on $O B S C N$ gene mutations and its association with other cancers were identified by intensive literature search and the detailed information such as cancer types, mutation profiles, co-mutating genes, amino acid variations and supporting citations are tabulated (Table 1).

\section{Functional analysis of differentially expressed $O B S C N$ gene in breast cancer}

Mutations in the OBSCN gene largely affect various interlinked proteins involved in cell adhesion and integration process [52]. Functional mutations in $O B S C N$ largely affects E-cadherin, $\alpha$-catenin and $\beta$-catenin expressions which initiate epithelial cells dispersions and subsequently increase the level of F-actin followed by cell migration [20, 53-55]. Actin filaments are vital for cellular mechanistic amoeboid movements accelerated by filapodia or pseudopodia like structures formed in cytoplasmic regions [56, 57]. A recent study showed that $O B S C N$ functional gene mutations are responsible for the loss of vital protein expressions [21]. The loss of $O B S C N$ appears to be consequent event in primary to metastatic breast cancer majorly affecting cellular integration. The protein kinases (PKs) are from the larger protein family involved in various cellular, structural and functional mechanisms in humans. The Serine/Threonine Kinase (STK) is one of the important protein kinase involved in cellular cytoskeletal and integration roles such as cell proliferation, differentiation and apoptotic process, etc. $[58,59]$. The STK actively binds with p120-catenin and regulates cadherin facilitated intercellular adhesions and E-cadherin-p120 bound complex also plays a crucial role in maintaining the equilibrium of cadherin levels $[60,61]$. The OBSCN mutations affect E-cadherin level, lead to flux in adherens junctions and increase cell disintegration followed by cell movement [62]. The OBSCN gene mutations heavily affect STK protein activity and also act as a ligand for small ankyrin1 (sANK1). sANK1 are integral proteins to the fundamental spectrin-actin cytoskeleton involved in cellular movement activation and proliferation, which cause metastasis [63]. Moreover, $O B S C N$ gene also acts as a kinome regulatory element that regulates few other kinase family proteins in either direct or indirect manner.

\section{Gene interaction analysis revealed that $O B S C N$ gene is positively correlated with protein binding and cell transition associated genes}

The OBSCN gene mutations have significant relationship with genes responsible for cellular structural and functional roles. Also, the expression of $O B S C N$ gene is positively correlated with few other genes such as TOPIMT, MYC, TARPBPI, ADCK3, TRIM17, and 


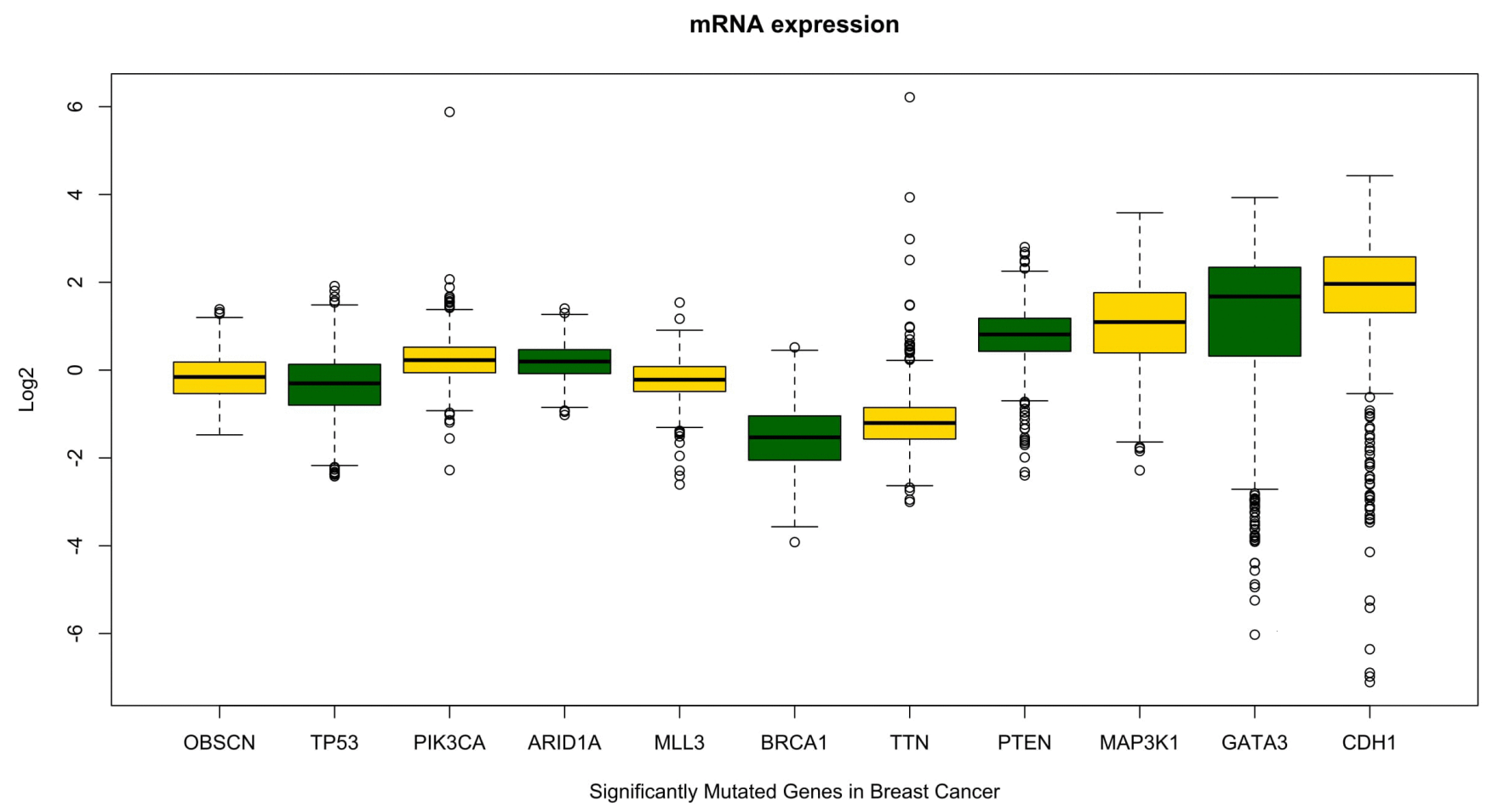

Figure 4: Comparative evaluation of $O B S C N$ gene expression pattern with other known breast cancer genes shows $O B S C N$ gene has similar expression pattern with some of the known breast cancer driver genes.
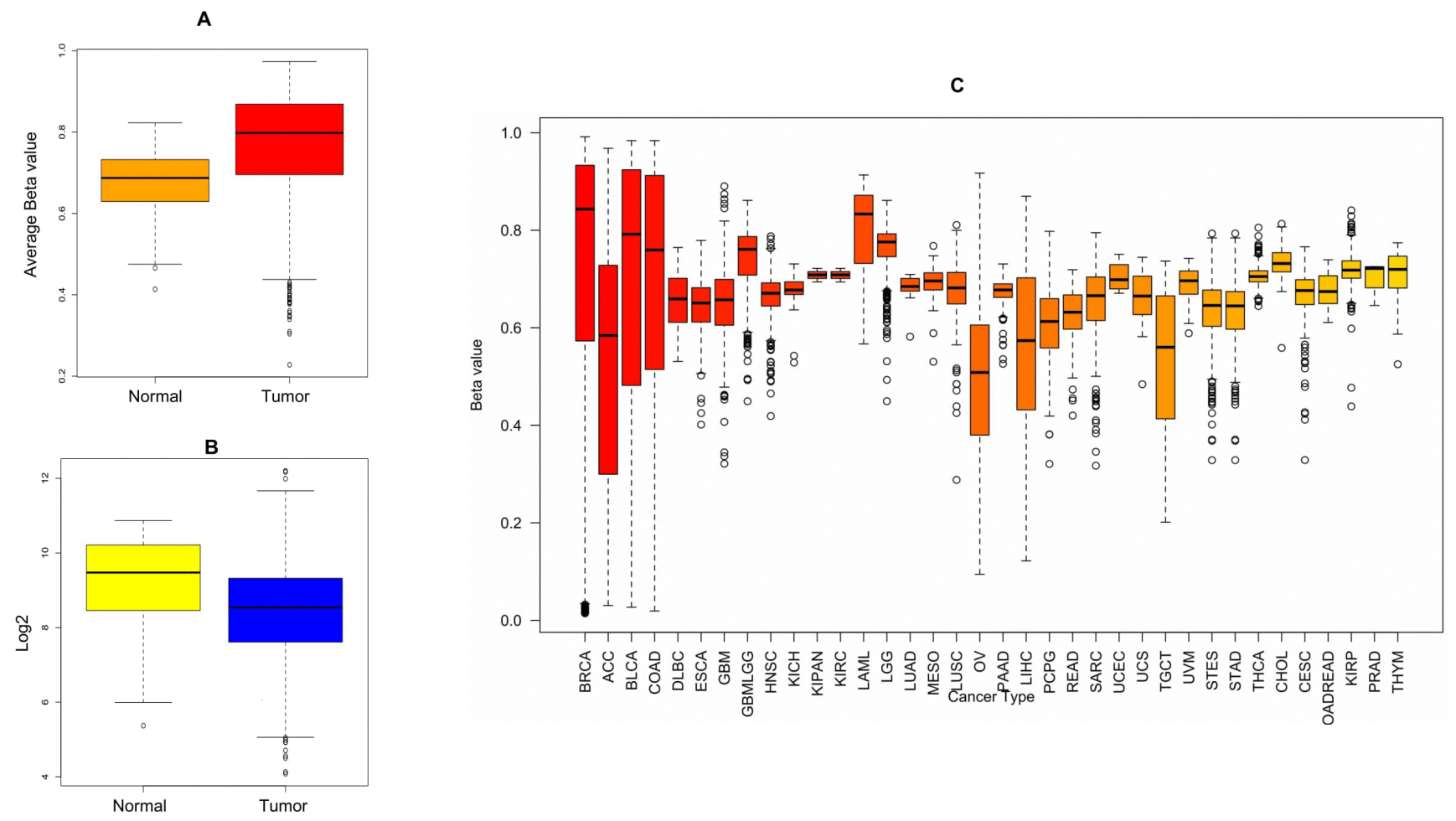

Figure 5: (A) OBSCN methylation profiles of normal $(n=98)$ and breast tumor samples $(n=720)$ comparison; (B) Gene expression comparison between normal and tumor samples; (C) Comparison of methylation profiles showed that $O B S C N$ gene largely hypermethylated in breast cancer than other cancer types. 
Table 1: The $O B S C N$ gene mutations and their associations with various cancer types

\begin{tabular}{|c|c|c|c|c|}
\hline Disease Types & Most common co-mutation with OBSCN gene & $\begin{array}{l}\text { Major mutations } \\
\text { type }\end{array}$ & $\begin{array}{c}\text { Specific } \\
\text { Amino acid } \\
\text { variations }\end{array}$ & References \\
\hline Breast Cancer & TP53 & Missense & NA & {$[13,21,35]$} \\
\hline $\begin{array}{l}\text { Lung Cancer; } \\
\text { Respiratory Disease }\end{array}$ & $\begin{array}{l}\text { TP53, ARIDIA, PTEN, KRAS, MYC, PIK3CA, } \\
\text { BRAF, EGFR, NRAS }\end{array}$ & Missense & NA & {$[36,37]$} \\
\hline $\begin{array}{l}\text { Gastrointestinal } \\
\text { Stromal tumor } \\
\text { and Leiomyosarcoma }\end{array}$ & C9orf65, TTN, SPEG & Missense & NA & {$[15,38,39]$} \\
\hline Colorectal cancer & TP53 & Missense & NA & {$[13,35]$} \\
\hline Prostate cancer & $\begin{array}{l}\text { CLDN7, STRA13, FLNA FAM83H, CLDN7, ARFGAP3, } \\
\text { KDM2A, }\end{array}$ & Missense & NA & {$[40,41]$} \\
\hline Melanoma & EPHA3, TTN & $\begin{array}{l}\text { Somatic } \\
\text { Missense }\end{array}$ & $\mathrm{E} 4574 \mathrm{~K}$ & {$[14]$} \\
\hline $\begin{array}{l}\text { Cervical/ Endometrial and } \\
\text { Ovarian cancer }\end{array}$ & $\begin{array}{l}\text { Tp53, PIK3CA, FBXW7, NEB, DNAH11, ORAI2, } \\
\text { RNF19B, SPTA1, UBA2, UTRN, BSN }\end{array}$ & Missense & NA & {$[42]$} \\
\hline Liver \& Pancreatic cancer & $\begin{array}{l}\text { ATPAF1, TRPM4, MLL3, ARID1A, ARID1B, ARID2, SOS1, } \\
\text { MROH1 }\end{array}$ & Missense & NA & {$[14,19,43,44]$} \\
\hline Glioblastoma & $T T N$ & $\begin{array}{l}\text { Germline } \\
\text { Missense }\end{array}$ & $\mathrm{R} 4558 \mathrm{H}$ & {$[13,14]$} \\
\hline Esophageal Cancer & C9orf65, TP53, ARID1A, MUC17 & Missense & NA & {$[45]$} \\
\hline Sarcoma & C9orf65, PRUNE2 & Missense & NA & {$[15]$} \\
\hline $\begin{array}{l}\text { Nephroblastoma and other } \\
\text { kidney cancers }\end{array}$ & PTHB1 & Missense & NA & {$[46,47]$} \\
\hline Cardiomyopathy & TTN, MYH7, DSP, VCL, LAMA4, MYOM1, TNNC1, TNNI3 & $\begin{array}{l}\text { Truncating } \\
\text { Mutation }\end{array}$ & NA & [47-51] \\
\hline
\end{tabular}

RND2. Initially we used metastatic breast cancer data (Metastatic Breast cancer-France 2016) for network analysis and revealed many participating genes such as RHOT2, RAC3, RHOD, ARHGEF7, PAK1, PDPK1, $A K T 3$, RIPK2, ERBB2, PRKD1, etc. which are positively correlated with amplification mutations and have strong association with cell proliferation, differentiation, tumorigenesis and other metastasis features. Similarly, we used British Columbia Xenografts (British Columbia, Nature 2014) data linked with many interesting genes such as RHOB, ITSN1, RHOD, ERBB2, AKT3, BRAF, CDK1, $M A S T L$ along with eight more genes which were highly correlated with cell signaling and cell migration functions. The breast invasive carcinoma (TCGA, Provisional) data showed that the $O B S C N$ had strong interaction with $P A K 1$ gene through $R H O U$ and $R A C 3$ genes. The breast cancer oncogene, $P A K 1$, acts as a hub gene connecting two sub networks. In first sub network, $P D P K 1$ gene a central gene linked with other significant genes such as $A K T 3, E R B B 2, S G K 3, P R K C B, P R K C Q$, etc. and the second sub network is connected with STK3, AURKA, $C S N K 1 D, N E K 2$, etc. The PAK1 and PDPK1 genes are strongly associated with breast tumorigenesis and cell migration in metastatic event $[64,65]$. Along with the afore-mentioned genes, $O B S C N$ is interconnected with other genes such as PAK2, AKT1, TP53RK, NEK2, WNK1, $C S N K 1 D$, etc. which are frequently mutated in invasive breast carcinoma (Nature 2012) (Cell 2015). The detailed $O B S C N$ mutation specific network neighbors were identified using functional protein association network using STRING (http://string-db.org/). Additional pathway specific networks were also used to identify and validate the genes involved in $O B S C N$ associated pathway using PCViz (http://www.pathwaycommons.org/) and detailed networks are illustrated in Figure 6.

\section{$O B S C N$ genetic alterations lead to cell survival and switches towards EMT}

Substantial evidences propose that $O B S C N$ functional mutations may have strong associations with Wnt signaling regulated by a series of activators along with $\beta$-catenin [66]. In the nucleus, $\beta$-catenin binds to transcription activation elements (TCF/LEF), leading to the activation of the target genes (specifically $C C N D 1$, $c-M Y C$, and $F N 1$ ) responsible for the regulation of cell proliferation and differentiation [67-69]. Mutational event of $O B S C N$ gene majorly affects $\beta$-catenin downstream signaling leading to lower down or over expression of genes such as $C C N D 1, c-M Y C$, and $F N 1$, which stimulates several types of cancers including breast, ovarian, lung, pancreatic, colorectal, and uterine carcinoma [70-75]. The elevated level of fibronectin or loss of proteins such as E-CADHERIN, B-CATENIN, etc. may cause cellular 
proliferation followed by EMT, which render patients overall survival. Henceforth, $O B S C N$ gene is believed to be an indirect regulator of fibronectin expression in breast and colon cancer $[72,76]$. The fibronectin malfunction may also affect vital proteins such as integrin and other transmembrane receptors responsible for cell-cell contact, extracellular matrix (ECM) communications, cell adhesion and accommodate several ligands such as collagen, laminin and vitronectin. Fibronectin is important protein which activates integrin and is involved in the regulation of cellular signal transduction, cell proliferation, gene expression and cytoskeletal reorganization [77]. Hence, the $O B S C N$ gene mutation perhaps affects the regulation of $\beta$-catenin and other regulatory elements in Wnt signaling pathway largely affects mainly the downstream genes and proteins expressions involved [78]. Interestingly in metastatic cancer, $O B S C N$ mutation observed with new list of interacting genes in Ras protein family members such as RHOD, RHOT2 and RAC3 are involved in major functions such as reorganization of actin cytoskeleton, GTPase activity, formation of lamellipodia, respectively [79-81, 99]. The RAC3 gene is important gene activates $P A K 1$, which is vital to stimulates F-actin formation leads to cell migration. Similarly, $P A K 1$ activates another important proliferation related protein, aurora kinase $(A U R K A)$ and it inhibits $I K B-\alpha$, which inhibits apoptosis through $N F$-кB and CIAPl genes [82, 83]. The detailed $O B S C N$ gene involved cancer-associated pathway illustrated in Figure 7. The Panther database (http://pantherdb.org/) was used to further validate gene
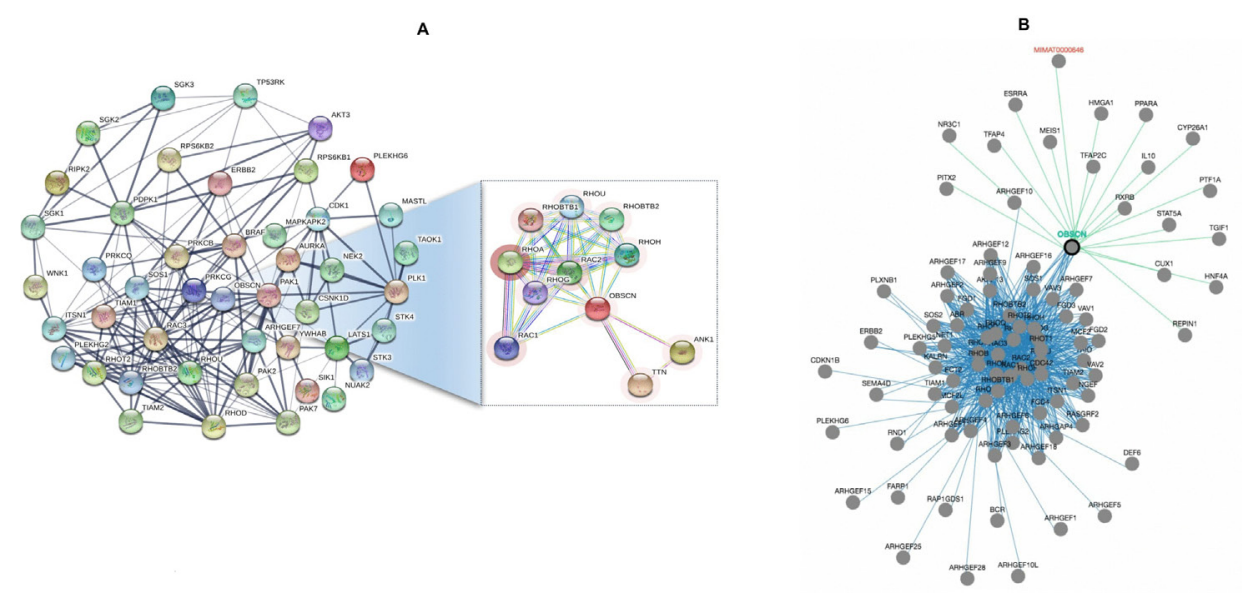

Figure 6: (A) Mutation specific $O B S C N$ functional association network and its interacting network partners identified using STRING database; (B) Gene specific interactions pathways were identified using pathway commons network visualizer and many interacting partners of $O B S C N$ are cancer-associated genes.

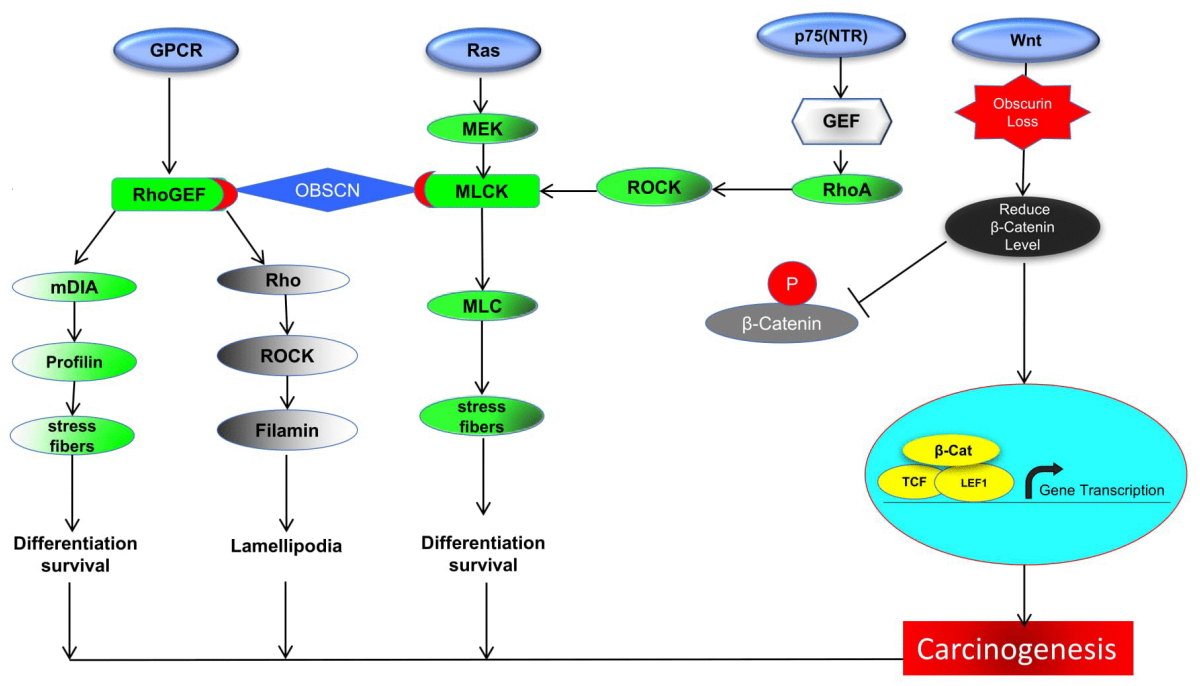

Figure 7: The $O B S C N$ gene involved either direct or indirect pathway of GPCR, Ras, p75 or Wnt signaling. (In GPCR pathway, $O B S C N$-RhoGEF is simultaneously regulates mDIA, Rho and their downstream genes which are involved in cell differentiation and lamellipodia formation; the other chain of $O B S C N$, MLCK and its downstream pathway activates MLC leads to formation of stress fiber which cause cell differentiation and survival; On the other way RhoA activated from p75 (NTR) pathway also involved in Ras pathway regulates down regulates MLCK; in Wnt signaling $O B S C N$ disequilibrium leads to $\beta$-catenin loss which leads to carcinogenesis. 
ontology based molecular functions analysis and further confirmed by evaluating fold enrichment scores [84]. The $O B S C N$ gene and their networks neighbors were involved in binding and cell regulatory mechanisms including cell adhesion and binding with several receptors and signaling molecules (Figure 8).

\section{Mutational tolerance profiles and their consequences in proteome level}

Recent studies on $O B S C N$ mutations uncover key amino acids mutations, which are crucial factor for many human diseases including cardiomyopathy and cancers. $[49,51,85]$. In this study, we also attempted to know the deep impact of $O B S C N$ mutations including the proteome level. The $O B S C N$ gene mutational protein variants retrieved from Ensembl genome browser (http:// asia.ensembl.org/) and their effects were predicted using
Variant Effect Predictor (VEP) tool (http://asia.ensembl. org/Tools/VEP) and wANNOVAR (http://wannovar. wglab.org/) [86, 87]. The SIFT (http://sift.jcvi.org/) and PolyPhen-2 (http://genetics.bwh.harvard.edu/pph2/) tools were used to achieve the most reliable protein variants prediction, and we also considered few other variants impact prediction algorithms such as Log ratio test (LRT), Mutation Taster (http://www.mutationtaster. org/), Mutation Assessor (http://mutationassessor.org/r3/), FATHMM (http://fathmm.biocompute.org.uk/) and Variant effect scoring tool 3 (VEST3)( http://karchinlab.org/apps/ appVest.html), etc. Most of the abovementioned tools predict the variants and their impacts based on sequence changes and very few tools also consider structural changes [88-96]. The variants predicted by the maximum number of tools were used to filter and used for further analysis (Figure 9) (http://compbio.berkeley.edu/proj/ varant/manual.html). From the overall analysis, it was

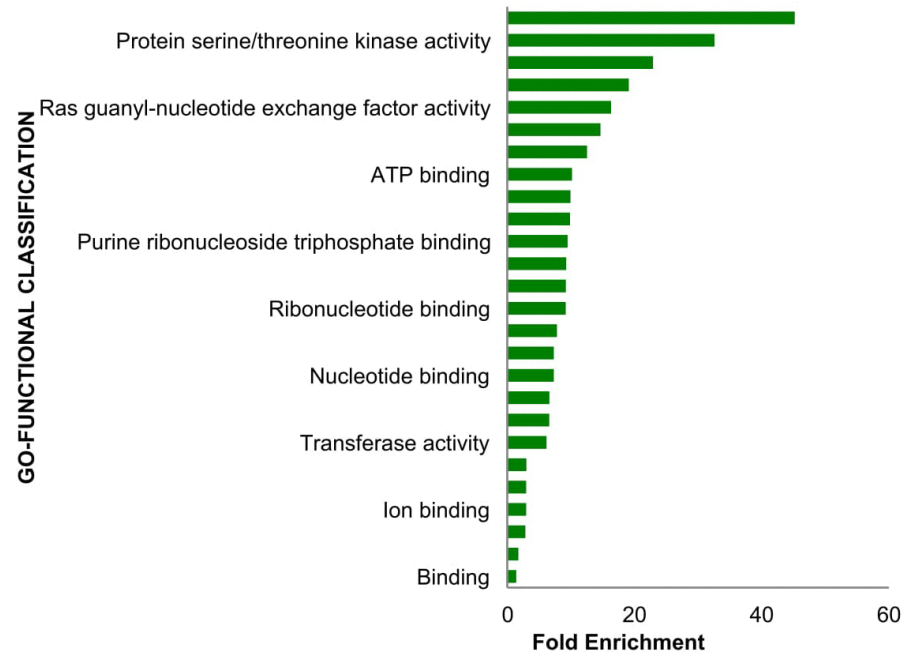

Figure 8: Molecular functional classification analysis of $O B S C N$ gene and its network neighbor genes showed that $O B S C N$ gene majorly involved in binding activity with various molecules.
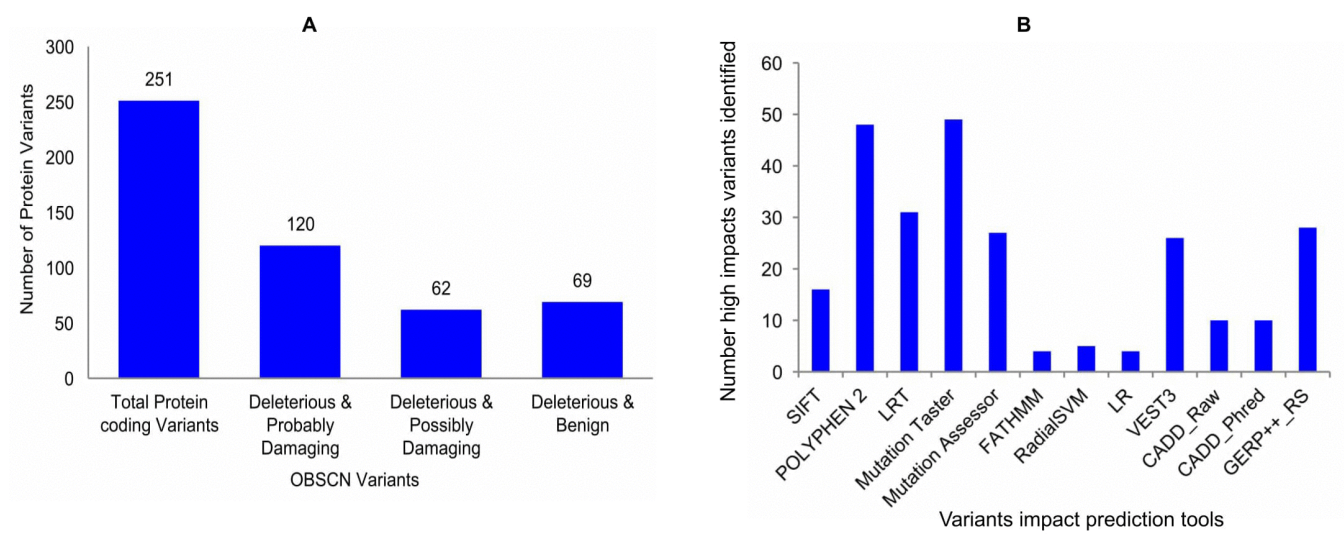

Figure 9: (A) SIFT and POLYPHEN-2 programs were used to predict the most common and significant $O B S C N$ mutational impact variants; (B) To validate the high-impact variants and their mutations impact are predicted using 10 potential impact prediction tools. 
seen that $O B S C N$ gene had a low tolerance against few functional mutations (total of 251 protein variants), half of the variants $(\sim 48 \%)$ exhibited deleterious and probably damaging effects (Supplementary Table 1), and rest of the variants came in deleterious \& possibly damaging and deleterious with benign categories [95, 97, 98]. The overlapping mutational impact variants were taken and further analyzed the somatic mutations using COSMIC database. The detailed $O B S C N$ mutational impact on protein levels are emphasized using lollipop plot of maftools (Bioconductor R-package) and amino acids variations and their impacts are indicated in various colors representations along with mutations count (Figure 10) (https:/github.com/PoisonAlien/mafTools). In addition, the key mutational variants, types, amino acid variations and impacts in domain levels are listed in Table 2.

\section{OBSCN mediated targeted anti-cancer therapy: a present and future perspectives}

Several interesting genes are interlinked with tumorigenesis including $O B S C N$ gene, which is considered the key gene among them. The $O B S C N$ gene may act as unique target for anti-cancer therapy in breast and other cancers, since it is having multiple interactions with intra and inter-cellular levels of numerous interconnecting proteins. In breast cancer targeted anti-cancer therapy, several key genes are targeted such as CTNND1, CDC42 and DVL. Over expression of P120-CATENIN tremendously inhibited several signaling molecules such as RHOA, RAC1 and CDC42 which are involved in the regulation of numerous cellular functions [100]. Similarly, downregulation of $C D C 42$ initiated cancer. Interestingly $O B S C N$ gene is an active target regulating $C D C 42$ downstream pathway accounting for the tumorigenesis [101]. DVL (Dishevelled homology1) protein phosphorylation are vital phenomenon accelerated by $C K 1 \varepsilon$ and RIPK4 in Wnt signaling pathway [102]. Hence, reduced $\beta$-catenin level and LRP6 association facilitates further downstream signaling of $\beta$-catenin, which activates transcription factors/ lymphoid enhancerbinding factors (TCF/LEF) involved in numerous cellular regulations and cell migrations. An alternative and most interesting target is DVL expression responsible for calmodulin-dependent protein kinase (CamK-II) activation followed by expression of F-actin. The F-actin is the key protein involved in cell division, contraction and locomotion and altered F-actin dynamics is most vital feature for epithelial to mesenchymal transition (EMT) of metastatic breast cancer. Hence, anti-cancer drug targets may actively repress DVL and it may potentially block F-actin dynamics, which inhibits EMT process in cancer cells, and the overall phenomena, is indirectly regulated by $O B S C N$ gene.

\section{Concluding remarks}

We have analyzed $O B S C N$ gene mutation, expression and methylation data and the data revealed that $O B S C N$ gene is one of most frequently mutated gene in various cancer types, especially in breast cancer. The $O B S C N$ gene mutation may play an essential role during cancer initiation and progression, largely distressed by various kinds of mutations in gene level due to loss of heterozygosity, various oncogenic factors, intra and intercellular environmental stress. Mutations in $O B S C N$ gene largely affects multiple properties of cells including cell adhesion and increase the integration and render cellular transitions and many more. Evaluation of $O B S C N$ mutational status may help early prognosis of metastatic potential of breast cancer. Mutational, copy number and epigenetic analysis of $O B S C N$ gene status may serve as a

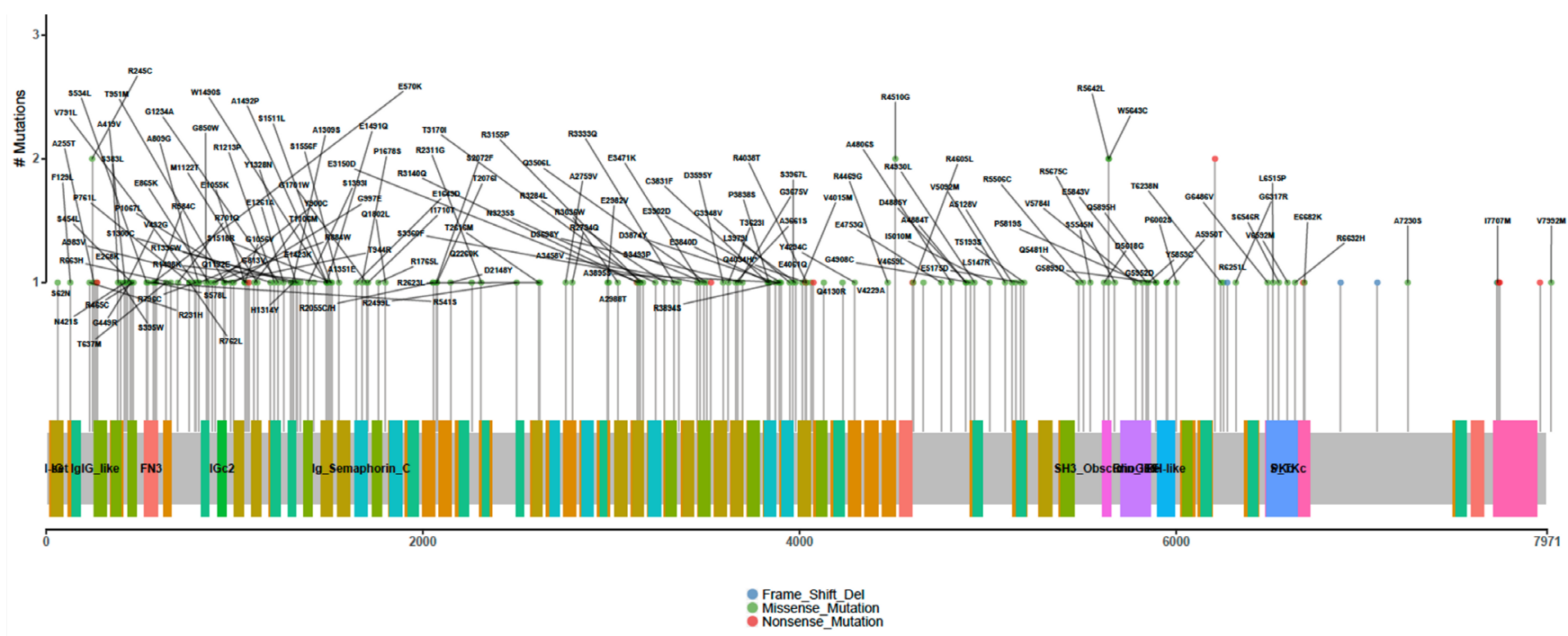

Figure 10: Lollipop plot function of maftools represents functional amino acids mutations and their impacts on various domains of $O B S C N$ gene are indicated in different colors representation. 
Table 2: The significant $O B S C N$ mutation variants and their impacts filtered from cBioPortal breast cancer patient tumor samples

\begin{tabular}{|c|c|c|c|c|c|}
\hline Genomic Coordinate & Reference and Variants & Mutation Type & Copy Number & Amino acid Variant & Major Domain Affected \\
\hline 228402602 & $\mathrm{C}>\mathrm{G}$ & Missense & AMP & $\mathrm{T} 544 \mathrm{~S}$ & Fibronectin-III \\
\hline 228412169 & NA & Missense & Gain & V888G & Ig-Domain \\
\hline 228432150 & $\mathrm{~T}>\mathrm{G}$ & Missense & Gain & V1212G & Ig-Domain \\
\hline 228432150 & NA & Missense & Gain & V1120G & Ig-Domain \\
\hline 228432244 & $\mathrm{G}>\mathrm{T}$ & Missense & Gain & Q1243H & Ig-Domain \\
\hline 228434340 & $\mathrm{C}>\mathrm{T}$ & Missense & Diploid & $\mathrm{T} 1382 \mathrm{M}$ & Ig-Domain \\
\hline 228461665 & $\mathrm{G}>\mathrm{A}$ & Missense & Gain & V1778M & Fibronectin-III \\
\hline 228464221 & $\mathrm{G}>-$ & Frameshift DEL & Del & V2282fs & Ig-Domain \\
\hline 228464225 & $->\mathrm{G}$ & Frameshift INS & Gain & Q2283fs & Ig-Domain \\
\hline 228479785 & NA & Missense & Gain & G3509V & Ig-Domain \\
\hline 228479785 & $\mathrm{G}>\mathrm{T}$ & Missense & Gain & G3938V & Ig-Domain \\
\hline 228479785 & $\mathrm{G}>\mathrm{T}$ & Missense & Gain & G3693V & Ig-Domain \\
\hline 228480325 & $\mathrm{~T}>\mathrm{C}$ & Missense & Gain & W3998R & Ig-Domain \\
\hline 228480325 & $\mathrm{~T}>\mathrm{C}$ & Missense & Gain & W3753R & Ig-Domain \\
\hline 228480325 & NA & Missense & Gain & W3569R & Ig-Domain \\
\hline 228481236 & $\mathrm{C}>\mathrm{T}$ & Missense & Gain & $\mathrm{R} 3868 \mathrm{C}$ & Ig-Domain \\
\hline 228491624 & $\mathrm{AC}>-$ & Frameshift DEL & Del & L4419fs & Ig-Domain \\
\hline 228492905 & $\mathrm{G}>\mathrm{C}$ & Missense & Gain & $\mathrm{S} 4538 \mathrm{~T}$ & Ig-Domain \\
\hline 228494273 & $\mathrm{G}>\mathrm{A}$ & Missense & Gain & E4911K & Ig-Domain \\
\hline 228494273 & NA & Missense & Gain & E3954K & Ig-Domain \\
\hline 228494979 & NA & Missense & AMP & K4071N & Ig-Domain \\
\hline 228497221 & $\mathrm{G}>\mathrm{A}$ & Missense & Gain & V5282M & Ig-Domain \\
\hline 228497221 & NA & Missense & Gain & V4325M & Ig-Domain \\
\hline 228497221 & $\mathrm{G}>\mathrm{A}$ & Missense & Gain & V5037M & Ig-Domain \\
\hline 228503574 & $\mathrm{G}>\mathrm{A}$ & Missense & Gain & E5059Q & Ig-Domain \\
\hline 228506585 & $\mathrm{~T}>\mathrm{C}$ & Missense & Gain & V5668A & SH3 \\
\hline 228506585 & NA & Missense & Gain & V4711A & Ig-Domain \\
\hline 228506585 & $\mathrm{~T}>\mathrm{C}$ & Missense & Gain & V5423A & Ig-Domain \\
\hline 228506947 & $\mathrm{G}>\mathrm{A}$ & Missense & Gain & A5544T & NA \\
\hline 228509882 & $\mathrm{G}>\mathrm{A}$ & Missense & Gain & E5826K & NA \\
\hline 228521392 & NA & Missense & Gain & S5322C & Ig-Domain \\
\hline 228521466 & $\mathrm{C}>\mathrm{T}$ & Missense & Gain & R6304W & NA \\
\hline 228521466 & NA & Missense & Gain & R5347W & Ig-Domain \\
\hline 228521466 & $\mathrm{C}>\mathrm{T}$ & Missense & Gain & R6059W & Ig-Domain \\
\hline 228537694 & $->\mathrm{T}$ & Frameshift INS & Gain & Y6796fs & NA \\
\hline 228538601 & $\mathrm{C}>\mathrm{T}$ & Nonsense & Gain & Q6838* & Ig-Domain \\
\hline 228547542 & $\mathrm{G}>\mathrm{A}$ & Missense & Gain & G6317R & NA \\
\hline 228556454 & $\mathrm{G}>\mathrm{T}$ & Missense & Gain & R7312L & STK-cat Domain \\
\hline 228559643 & $\mathrm{C}>\mathrm{A}$ & Missense & Gain & P7767Q & NA \\
\hline 228559663 & $\mathrm{C}>\mathrm{T}$ & Missense & Gain & P7774S & Protein Kinase 2 \\
\hline
\end{tabular}

*Ig- Immunoglobulin. AMP-Amplification; Del-Deletion 
tool for the prediction of targeted anti-cancer drugs, which will be helpful for targeted breast cancer therapy $[11,20]$. Further functional studies on $O B S C N$ gene in various model systems with gene overexpression and/or targeted disruption should also greatly facilitate these processes.

\section{ACKNOWLEDGMENTS AND FUNDING}

We thank members of the Professor Deng laboratory for critical reading and discussion. This work is supported by the Chair Professor Grant (CPG2017-00026-FHS), MYRG2016-00132-FHS and MYRG2016-00139 of University of Macau and FDCT grants (065/2015/A2 and 094/2015/A3) to Chu-Xia Deng.

\section{CONFLICTS OF INTEREST}

Authors declare no conflicts of interest.

\section{REFERENCES}

1. Kalluri R, Weinberg RA. The basics of epithelialmesenchymal transition. J Clin Invest. 2009; 119:1420-1428.

2. Thiery JP, Acloque H, Huang RY, Nieto MA. Epithelialmesenchymal transitions in development and disease. Cell. 2009; 139:871-890.

3. Russell MW, Raeker MO, Korytkowski KA, Sonneman KJ. Identification, tissue expression and chromosomal localization of human Obscurin-MLCK, a member of the titin and Dbl families of myosin light chain kinases. Gene. 2002; 282:237-246.

4. Young P, Ehler E, Gautel M. Obscurin, a giant sarcomeric Rho guanine nucleotide exchange factor protein involved in sarcomere assembly. J Cell Biol. 2001; 154:123-136.

5. Borisov AB, Raeker MO, Kontrogianni-Konstantopoulos A, Yang K, Kurnit DM, Bloch RJ, Russell MW. Rapid response of cardiac obscurin gene cluster to aortic stenosis: differential activation of Rho-GEF and MLCK and involvement in hypertrophic growth. Biochem Biophys Res Commun. 2003; 310:910-918.

6. Kontrogianni-Konstantopoulos A, Catino DH, Strong JC, Bloch RJ. De novo myofibrillogenesis in $\mathrm{C} 2 \mathrm{C} 12$ cells: evidence for the independent assembly of $\mathrm{M}$ bands and $\mathrm{Z}$ disks. Am J Physiol Cell Physiol. 2006; 290:C626-637.

7. Kontrogianni-Konstantopoulos A, Ackermann MA, Bowman AL, Yap SV, Bloch RJ. Muscle giants: molecular scaffolds in sarcomerogenesis. Physiol Rev. 2009; 89:1217-1267.

8. Fukuzawa A, Idowu S, Gautel M. Complete human gene structure of obscurin: implications for isoform generation by differential splicing. J Muscle Res Cell Motil. 2005; 26:427-434

9. Petersen TE, Thogersen HC, Skorstengaard K, Vibe-Pedersen K, Sahl P, Sottrup-Jensen L, Magnusson S. Partial primary structure of bovine plasma fibronectin: three types of internal homology. Proc Natl Acad Sci USA. 1983; 80:137-141.
10. Kamm KE, Stull JT. Signaling to myosin regulatory light chain in sarcomeres. J Biol Chem. 2011; 286:9941-9947.

11. Perry NA, Vitolo MI, Martin SS, Kontrogianni-Konstantopoulos A. Loss of the obscurin-RhoGEF downregulates RhoA signaling and increases microtentacle formation and attachment of breast epithelial cells. Oncotarget. 2014; 5:8558-8568. https://doi.org/10.18632/oncotarget.2338.

12. Shriver M, Stroka KM, Vitolo MI, Martin S, Huso DL, Konstantopoulos K, Kontrogianni-Konstantopoulos A. Loss of giant obscurins from breast epithelium promotes epithelial-to-mesenchymal transition, tumorigenicity and metastasis. Oncogene. 2015; 34:4248-4259.

13. Sjöblom T, Jones S, Wood LD, Parsons DW, Lin J, Barber TD, Mandelker D, Leary RJ, Ptak J, Silliman N, Szabo S, Buckhaults $\mathrm{P}$, Farrell C, et al. The consensus coding sequences of human breast and colorectal cancers. Science. 2006; 314:268-274.

14. Balakrishnan A, Bleeker FE, Lamba S, Rodolfo M, Daniotti M, Scarpa A, van Tilborg AA, Leenstra S, Zanon C, Bardelli A. Novel somatic and germline mutations in cancer candidate genes in glioblastoma, melanoma, and pancreatic carcinoma. Cancer Res. 2007; 67:3545-3550.

15. Price ND, Trent J, El-Naggar AK, Cogdell D, Taylor E, Hunt KK, Pollock RE, Hood L, Shmulevich I, Zhang W. Highly accurate two-gene classifier for differentiating gastrointestinal stromal tumors and leiomyosarcomas. Proc Natl Acad Sci USA. 2007; 104:3414-3419.

16. Rajendran BK, Deng CX. Characterization of potential driver mutations involved in human breast cancer by computational approaches. Oncotarget. 2017; 8:5025250272. https://doi.org/10.18632/oncotarget.17225.

17. Liu Y, Hu Z, DeLisi C. Mutated Pathways as a Guide to Adjuvant Therapy Treatments for Breast Cancer. Mol Cancer Ther. 2016; 15:184-189.

18. Waalkes S, Atschekzei F, Kramer MW, Hennenlotter J, Vetter G, Becker JU, Stenzl A, Merseburger AS, Schrader AJ, Kuczyk MA, Serth J. Fibronectin 1 mRNA expression correlates with advanced disease in renal cancer. BMC Cancer. 2010; 10:503.

19. Bii VM, Trobridge GD. Identifying Cancer Driver Genes Using Replication-Incompetent Retroviral Vectors. Cancers (Basel). 2016; 8.

20. Shriver M, Marimuthu S, Paul C, Geist J, Seale T, Konstantopoulos K, Kontrogianni-Konstantopoulos A. Giant obscurins regulate the PI3K cascade in breast epithelial cells via direct binding to the $\mathrm{PI} 3 \mathrm{~K} / \mathrm{p} 85$ regulatory subunit. Oncotarget. 2016; 7:45414-45428. https://doi.org/10.18632/ oncotarget.9985.

21. Perry NA, Shriver M, Mameza MG, Grabias B, Balzer E, Kontrogianni-Konstantopoulos A. Loss of giant obscurins promotes breast epithelial cell survival through apoptotic resistance. FASEB J. 2012; 26:2764-2775.

22. Anastasiadis PZ, Reynolds AB. The p120 catenin family: complex roles in adhesion, signaling and cancer. J Cell Sci. 2000; 113:1319-1334.

23. Yap AS. The morphogenetic role of cadherin cell adhesion molecules in human cancer: a thematic review. Cancer Invest. 1998; 16:252-261. 
24. Vega FM, Ridley AJ. Rho GTPases in cancer cell biology. FEBS Lett. 2008; 582:2093-2101.

25. Rossman KL, Der CJ, Sondek J. GEF means go: turning on RHO GTPases with guanine nucleotide-exchange factors. Nat Rev Mol Cell Biol. 2005; 6:167-180.

26. Hall A. The cytoskeleton and cancer. Cancer Metastasis Rev. 2009; 28:5-14.

27. Sahai E. Mechanisms of cancer cell invasion. Curr Opin Genet Dev. 2005; 15:87-96.

28. Yamaguchi H, Condeelis J. Regulation of the actin cytoskeleton in cancer cell migration and invasion. Biochim Biophys Acta. 2007; 1773:642-652.

29. Whipple RA, Balzer EM, Cho EH, Matrone MA, Yoon JR, Martin SS. Vimentin filaments support extension of tubulinbased microtentacles in detached breast tumor cells. Cancer Res. 2008; 68:5678-5688.

30. Balzer EM, Whipple RA, Thompson K, Boggs AE, Slovic J, Cho EH, Matrone MA, Yoneda T, Mueller SC, Martin SS. c-Src differentially regulates the functions of microtentacles and invadopodia. Oncogene. 2010; 29:6402-6408.

31. Matrone MA, Whipple RA, Thompson K, Cho EH, Vitolo MI, Balzer EM, Yoon JR, Ioffe OB, Tuttle KC, Tan M, Martin SS. Metastatic breast tumors express increased tau, which promotes microtentacle formation and the reattachment of detached breast tumor cells. Oncogene. 2010; 29:3217-3227.

32. Mermel CH, Schumacher SE, Hill B, Meyerson ML, Beroukhim R, Getz G. GISTIC2.0 facilitates sensitive and confident localization of the targets of focal somatic copynumber alteration in human cancers. Genome Biol. 2011; 12:R41.

33. Shen R, Olshen AB, Ladanyi M. Integrative clustering of multiple genomic data types using a joint latent variable model with application to breast and lung cancer subtype analysis. Bioinformatics. 2009; 25:2906-2912.

34. Ali HR, Rueda OM, Chin SF, Curtis C, Dunning MJ, Aparicio SA, Caldas C. Genome-driven integrated classification of breast cancer validated in over 7,500 samples. Genome Biol. 2014; 15:431.

35. Caldas C, Edwards PA. A quantum leap in our knowledge of breast cancer mutations. Breast Cancer Res. 2006; 8:304.

36. Babur O, Gonen M, Aksoy BA, Schultz N, Ciriello G, Sander C, Demir E. Systematic identification of cancer driving signaling pathways based on mutual exclusivity of genomic alterations. Genome Biol. 2015; 16:45.

37. Kim JH, Park B, Pasaje CF, Kim Y, Bae JS, Park JS, Uh ST, Kim YH, Kim MK, Choi IS, Cho SH, Choi BW, Koh I, et al. Contribution of the OBSCN nonsynonymous variants to aspirin exacerbated respiratory disease susceptibility in Korean population. DNA Cell Biol. 2012; 31:1001-1009.

38. Greenman C, Stephens P, Smith R, Dalgliesh GL, Hunter C, Bignell G, Davies H, Teague J, Butler A, Stevens C, Edkins S, O'Meara S, Vastrik I, et al. Patterns of somatic mutation in human cancer genomes. Nature. 2007; 446:153-158.
39. Zang ZJ, Ong CK, Cutcutache I, Yu W, Zhang SL, Huang D, Ler LD, Dykema K, Gan A, Tao J, Lim S, Liu Y, Futreal $\mathrm{PA}$, et al. Genetic and structural variation in the gastric cancer kinome revealed through targeted deep sequencing. Cancer Res. 2011; 71:29-39.

40. Nalla AK, Williams TF, Collins CP, Rae DT, Trobridge GD. Lentiviral vector-mediated insertional mutagenesis screen identifies genes that influence androgen independent prostate cancer progression and predict clinical outcome. Mol Carcinog. 2016; 55:1761-1771.

41. Schinke EN, Bii V, Nalla A, Rae DT, Tedrick L, Meadows GG, Trobridge GD. A novel approach to identify driver genes involved in androgen-independent prostate cancer. Mol Cancer. 2014; 13:120.

42. Kuhn E, Wu RC, Guan B, Wu G, Zhang J, Wang Y, Song L, Yuan X, Wei L, Roden RB, Kuo KT, Nakayama K, Clarke $\mathrm{B}$, et al. Identification of molecular pathway aberrations in uterine serous carcinoma by genome-wide analyses. J Natl Cancer Inst. 2012; 104:1503-1513.

43. Fujimoto A, Totoki Y, Abe T, Boroevich KA, Hosoda F, Nguyen HH, Aoki M, Hosono N, Kubo M, Miya F, Arai Y, Takahashi $\mathrm{H}$, Shirakihara $\mathrm{T}$, et al. Whole-genome sequencing of liver cancers identifies etiological influences on mutation patterns and recurrent mutations in chromatin regulators. Nat Genet. 2012; 44:760-764.

44. Ranzani M, Annunziato S, Calabria A, Brasca S, Benedicenti F, Gallina P, Naldini L, Montini E. Lentiviral vector-based insertional mutagenesis identifies genes involved in the resistance to targeted anticancer therapies. Mol Ther. 2014; 22:2056-2068.

45. Shimizu T, Marusawa H, Matsumoto Y, Inuzuka T, Ikeda A, Fujii Y, Minamiguchi S, Miyamoto S, Kou T, Sakai Y, Crabtree JE, Chiba T. Accumulation of somatic mutations in TP53 in gastric epithelium with Helicobacter pylori infection. Gastroenterology. 2014; 147:407-417 e403.

46. Vernon EG, Malik K, Reynolds $\mathrm{P}$, Powlesland $\mathrm{R}$, Dallosso AR, Jackson S, Henthorn K, Green ED, Brown KW. The parathyroid hormone-responsive B1 gene is interrupted by a $\mathrm{t}(1 ; 7)(\mathrm{q} 42 ; \mathrm{p} 15)$ breakpoint associated with Wilms' tumour. Oncogene. 2003; 22:1371-1380.

47. Perry NA, Ackermann MA, Shriver M, Hu LY, Kontrogianni-Konstantopoulos A. Obscurins: unassuming giants enter the spotlight. IUBMB Life. 2013; 65:479-486.

48. Wu Y, Bell SP, Trombitas K, Witt CC, Labeit S, LeWinter MM, Granzier H. Changes in titin isoform expression in pacinginduced cardiac failure give rise to increased passive muscle stiffness. Circulation. 2002; 106:1384-1389.

49. Arimura $\mathrm{T}$, Matsumoto $\mathrm{Y}$, Okazaki O, Hayashi $\mathrm{T}$, Takahashi M, Inagaki N, Hinohara K, Ashizawa N, Yano K, Kimura A. Structural analysis of obscurin gene in hypertrophic cardiomyopathy. Biochem Biophys Res Commun. 2007; 362:281-287.

50. Borisov AB, Sutter SB, Kontrogianni-Konstantopoulos A, Bloch RJ, Westfall MV, Russell MW. Essential role of 
obscurin in cardiac myofibrillogenesis and hypertrophic response: evidence from small interfering RNA-mediated gene silencing. Histochem Cell Biol. 2006; 125:227-238.

51. Marston S, Montgiraud C, Munster AB, Copeland O, Choi O, Dos Remedios C, Messer AE, Ehler E, Knoll R. OBSCN Mutations Associated with Dilated Cardiomyopathy and Haploinsufficiency. PLoS One. 2015; 10:e138568.

52. Schlessinger J, Ullrich A. Growth factor signaling by receptor tyrosine kinases. Neuron. 1992; 9:383-391.

53. Rimm DL, Koslov ER, Kebriaei P, Cianci CD, Morrow JS. Alpha 1(E)-catenin is an actin-binding and -bundling protein mediating the attachment of F-actin to the membrane adhesion complex. Proc Natl Acad Sci USA. 1995; 92:8813-8817.

54. Shankar J, Nabi IR. Actin cytoskeleton regulation of epithelial mesenchymal transition in metastatic cancer cells. PLoS One. 2015; 10:e0119954.

55. Mege RM, Ishiyama N. Integration of Cadherin Adhesion and Cytoskeleton at Adherens Junctions. Cold Spring Harb Perspect Biol. 2017.

56. Arjonen A, Kaukonen R, Ivaska J. Filopodia and adhesion in cancer cell motility. Cell Adh Migr. 2011; 5:421-430.

57. Jacquemet G, Hamidi H, Ivaska J. Filopodia in cell adhesion, 3D migration and cancer cell invasion. Curr Opin Cell Biol. 2015; 36:23-31.

58. Capra M, Nuciforo PG, Confalonieri S, Quarto M, Bianchi M, Nebuloni M, Boldorini R, Pallotti F, Viale G, Gishizky ML, Draetta GF, Di Fiore PP Frequent alterations in the expression of serine/threonine kinases in human cancers. Cancer Res. 2006; 66:8147-8154.

59. Lahiry P, Torkamani A, Schork NJ, Hegele RA. Kinase mutations in human disease: interpreting genotypephenotype relationships. Nat Rev Genet. 2010; 11:60-74.

60. Ireton RC, Davis MA, van Hengel J, Mariner DJ, Barnes K, Thoreson MA, Anastasiadis PZ, Matrisian L, Bundy LM, Sealy L, Gilbert B, Roy VF, Reynolds AB. A novel role for p120 catenin in E-cadherin function. J Cell Biol. 2002; 159:465-476.

61. Xia X, Mariner DJ, Reynolds AB. Adhesion-associated and PKC-modulated changes in serine/threonine phosphorylation of p120-catenin. Biochemistry. 2003; 42:9195-9204.

62. Heuberger J, Birchmeier W. Interplay of cadherin-mediated cell adhesion and canonical Wnt signaling. Cold Spring Harb Perspect Biol. 2010; 2:a002915.

63. Kontrogianni-Konstantopoulos A, Jones EM, Van Rossum DB, Bloch RJ. Obscurin is a ligand for small ankyrin 1 in skeletal muscle. Mol Biol Cell. 2003; 14:1138-1148.

64. Shrestha Y, Schafer EJ, Boehm JS, Thomas SR, He F, Du J, Wang S, Barretina J, Weir BA, Zhao JJ, Polyak K, Golub TR, Beroukhim R, Hahn WC. PAK1 is a breast cancer oncogene that coordinately activates MAPK and MET signaling. Oncogene. 2012; 31:3397-3408.

65. Du J, Yang M, Chen S, Li D, Chang Z, Dong Z. PDK1 promotes tumor growth and metastasis in a spontaneous breast cancer model. Oncogene. 2016; 35:3314-3323.
66. Gottardi CJ, Gumbiner BM. Distinct molecular forms of beta-catenin are targeted to adhesive or transcriptional complexes. J Cell Biol. 2004; 167:339-349.

67. Gao ZH, Lu C, Wang MX, Han Y, Guo LJ. Differential betacatenin expression levels are associated with morphological features and prognosis of colorectal cancer. Oncol Lett. 2014; 8:2069-2076.

68. Maretzky T, Reiss K, Ludwig A, Buchholz J, Scholz F, Proksch E, de Strooper B, Hartmann D, Saftig P. ADAM10 mediates E-cadherin shedding and regulates epithelial cellcell adhesion, migration, and beta-catenin translocation. Proc Natl Acad Sci. USA. 2005; 102:9182-9187.

69. Haspel J, Grumet M. The L1CAM extracellular region: a multi-domain protein with modular and cooperative binding modes. Front Biosci. 2003; 8:s1210-1225.

70. Mylona E, Tzelepis K, Theohari I, Giannopoulou I, Papadimitriou C, Nakopoulou L. Cyclin D1 in invasive breast carcinoma: favourable prognostic significance in unselected patients and within subgroups with an aggressive phenotype. Histopathology. 2013; 62:472-480.

71. Xu P, Zhao M, Liu Z, Liu Y, Chen Y, Luo R, Fang W. Elevated nuclear CCND1 expression confers an unfavorable prognosis for early stage lung adenocarcinoma patients. Int J Clin Exp Pathol. 2015; 8:15887-15894.

72. Williams CM, Engler AJ, Slone RD, Galante LL, Schwarzbauer JE. Fibronectin expression modulates mammary epithelial cell proliferation during acinar differentiation. Cancer Res. 2008; 68:3185-3192.

73. Xu J, Chen Y, Huo D, Khramtsov A, Khramtsova G, Zhang C, Goss KH, Olopade OI. beta-catenin regulates c-Myc and CDKN1A expression in breast cancer cells. Mol Carcinog. 2016; 55:431-439.

74. Ross JS, Ali SM, Wang K, Palmer G, Yelensky R, Lipson D, Miller VA, Zajchowski D, Shawver LK, Stephens PJ. Comprehensive genomic profiling of epithelial ovarian cancer by next generation sequencing-based diagnostic assay reveals new routes to targeted therapies. Gynecol Oncol. 2013; 130:554-559.

75. Chen Y, McGee J, Chen X, Doman TN, Gong X, Zhang Y, Hamm N, Ma X, Higgs RE, Bhagwat SV, Buchanan S, Peng $\mathrm{SB}$, Staschke KA. Identification of druggable cancer driver genes amplified across TCGA datasets. PLoS One. 2014; 9:e98293.

76. Gavert N, Conacci-Sorrell M, Gast D, Schneider A, Altevogt P, Brabletz T, Ben-Ze'ev A. L1, a novel target of beta-catenin signaling, transforms cells and is expressed at the invasive front of colon cancers. J Cell Biol. 2005; 168:633-642.

77. Yao ES, Zhang H, Chen YY, Lee B, Chew K, Moore D, Park C. Increased betal integrin is associated with decreased survival in invasive breast cancer. Cancer Res. 2007; 67:659-664.

78. Gradl D, Kuhl M, Wedlich D. The Wnt/Wg signal transducer beta-catenin controls fibronectin expression. Mol Cell Biol. 1999; 19:5576-5587.

79. De Langhe S, Haataja L, Senadheera D, Groffen J, Heisterkamp N. Interaction of the small GTPase Rac3 with 
NRBP, a protein with a kinase-homology domain. Int J Mol Med. 2002; 9:451-459.

80. Shimizu F, Watanabe TK, Okuno S, Omori Y, Fujiwara T, Takahashi E, Nakamura Y. Isolation of a novel human cDNA (rhoHP1) homologous to rho genes. Biochim Biophys Acta. 1997; 1351:13-16.

81. Fransson S, Ruusala A, Aspenstrom P. The atypical Rho GTPases Miro-1 and Miro-2 have essential roles in mitochondrial trafficking. Biochem Biophys Res Commun. 2006; 344:500-510.

82. Hannak E, Kirkham M, Hyman AA, Oegema K. Aurora-A kinase is required for centrosome maturation in Caenorhabditis elegans. J Cell Biol. 2001; 155:1109-1116.

83. Zhao ZS, Lim JP, Ng YW, Lim L, Manser E. The GITassociated kinase PAK targets to the centrosome and regulates Aurora-A. Mol Cell. 2005; 20:237-249.

84. Mi H, Muruganujan A, Casagrande JT, Thomas PD. Large-scale gene function analysis with the PANTHER classification system. Nat Protoc. 2013; 8:1551-1566.

85. Ackermann MA, Shriver M, Perry NA, Hu LY, Kontrogianni-Konstantopoulos A. Obscurins: Goliaths and Davids take over non-muscle tissues. PLoS One. 2014; 9:e88162.

86. McLaren W, Gil L, Hunt SE, Riat HS, Ritchie GR, Thormann A, Flicek P, Cunningham F. The Ensembl Variant Effect Predictor. Genome Biol. 2016; 17:122.

87. Yang $H$, Wang $K$. Genomic variant annotation and prioritization with ANNOVAR and wANNOVAR. Nat Protoc. 2015; 10:1556-1566.

88. Chun S, Fay JC. Identification of deleterious mutations within three human genomes. Genome Res. 2009; 19:1553-1561.

89. Schwarz JM, Rodelsperger C, Schuelke M, Seelow D. MutationTaster evaluates disease-causing potential of sequence alterations. Nat Methods. 2010; 7:575-576.

90. Reva B, Antipin Y, Sander C. Predicting the functional impact of protein mutations: application to cancer genomics. Nucleic Acids Res. 2011; 39:e118.

91. Shihab HA, Gough J, Mort M, Cooper DN, Day IN, Gaunt TR. Ranking non-synonymous single nucleotide polymorphisms based on disease concepts. Hum Genomics. 2014; 8:11.

92. Carter H, Douville C, Stenson PD, Cooper DN, Karchin R. Identifying Mendelian disease genes with the variant effect scoring tool. BMC Genomics. 2013; 14:S3.

93. Kircher M, Witten DM, Jain P, O'Roak BJ, Cooper GM, Shendure J. A general framework for estimating the relative pathogenicity of human genetic variants. Nat Genet. 2014; 46:310-315.

94. Davydov EV, Goode DL, Sirota M, Cooper GM, Sidow A, Batzoglou S. Identifying a high fraction of the human genome to be under selective constraint using GERP++. PLoS Comput Biol. 2010; 6:e1001025.

95. Kumar P, Henikoff S, Ng PC. Predicting the effects of coding non-synonymous variants on protein function using the SIFT algorithm. Nat Protoc. 2009; 4:1073-1081.

96. Adzhubei IA, Schmidt S, Peshkin L, Ramensky VE, Gerasimova A, Bork P, Kondrashov AS, Sunyaev SR. A method and server for predicting damaging missense mutations. Nat Methods. 2010; 7:248-249.

97. Adzhubei I, Jordan DM, Sunyaev SR. Predicting functional effect of human missense mutations using PolyPhen-2. Curr Protoc Hum Genet. 2013; Chapter 7:Unit7 20.

98. Chang X, Wang K. wANNOVAR: annotating genetic variants for personal genomes via the web. J Med Genet. 2012; 49:433-436.

99. Dovas A, Couchman JR. RhoGDI: multiple functions in the regulation of Rho family GTPase activities. Biochem J. 2005; 390:1-9.

100. Qadir MI, Parveen A, Ali M. Cdc42: Role in Cancer Management. Chem Biol Drug Des. 2015; 86:432-439.

101. Gao C, Xiao G, Hu J. Regulation of Wnt/beta-catenin signaling by posttranslational modifications. Cell Biosci. 2014; 4:13.

102. Akhshi TK, Wernike D, Piekny A. Microtubules and actin crosstalk in cell migration and division. Cytoskeleton (Hoboken). 2014; 71:1-23. 